\title{
Municipal management of construction and demolition waste: influence of disposal fees
}

\author{
Laís Peixoto Rosado \\ Carmenlucia Santos Giordano Penteado
}

${ }^{I}$ School of Technology, UNICAMP, Limeira, SP, Brazil.

II School of Technology, UNICAMP, Limeira, SP, Brazil.

\begin{abstract}
Fiscal economic instruments are one of the main mechanisms to improve the management of construction and demolition waste (C\&DW), and the establishment of specific disposal fees is one of the most effective practices. This study analyzed the influence of increasing $C \& D W$ disposal fees considering a municipal management system. The environmental profile of the current scenario and the proposed scenarios, designed in accordance with the adoption of economic fiscal instruments, were determined through life cycle assessment. The results indicated that the scenario proposed for 2030 (350\% increase in disposal fees compared to 2017) has the lowest environmental impact, indicating the potential benefits of using tax instruments.
\end{abstract}

Keywords: Construction and demolition waste; management; economic instruments; life cycle assessment.

São Paulo. Vol. 23, 2020

Original Article

DOI: http://dx.doi.org/10.1590/1809-4422asoc20200032r1vu2020L6AO 


\section{Introduction}

Construction waste is globally recognized as one of the greatest challenges for the government. Among the main reasons, the high generation rates and its heterogeneous composition stand out (DAHLBO et al., 2015; UMAR et al., 2017; YAZDANBAKHSH, 2018). In Brazil, despite the existence of CONAMA Resolution No. 307 of 2002 (BRASIL, 2002), which regulates the management of construction and demolition waste (C\&DW), municipalities report the occurrence of irregular disposals, with environmental, economic and social impacts (IPEA, 2012).

$\mathrm{C} \& \mathrm{DW}$ is composed of a mineral fraction (concrete, mortar, bricks, ceramics) and other diverse fractions, such as plastics, metals, glass, wood, cardboard packaging, plaster, paints, oils and solvents. As there is the possibility of the existence of hazardous waste, segregation at the generating source is essential to ensure adequate reuse and recycling, as well as to prevent environmental contamination and public health risks (SINDUSCON-SP, 2015).

The generation sources range from small renovation works, often informal, to largescale construction and demolition. Regardless of the volume produced, the generator is responsible for the proper management of waste. However, municipalities must provide free collection systems for small generators, which produce up to 1 ton of C\&DW per day (BRASIL, 2002). In many cases, even with the existence of collection points, there is incidence of irregular disposals (ROSADO and PENTEADO, 2018a), increasing municipal spending on public cleaning. In medium and large municipalities, the amount of C\&DW generated can exceed the amount of municipal solid waste (MSW), mainly due to its high volume and density (MARQUES NETO, 2009). As the composition of $\mathrm{C} \& D W$ is not generally associated with major odor and visual pollution issues compared to MSW, its management ends up being neglected by the municipal government. However, it is worth mentioning that irregular C\&DW disposal may result in the proliferation of disease-causing vectors, such as dengue, and encourage the disposal of other materials by the population, leading to the emergence of environmental liabilities that can compromise the location from a sanitary point of view.

So far, there is no concrete data on the total generation of C\&DW in Brazil, as the available information, which reveals that the municipal cleaning services collected, in 2018, 122,012 tons per day of this type of waste (ABRELPE, 2019), does not consider the waste generated in large private works. In this way, the per capita generation rate of $510 \mathrm{~kg}$ of C\&DW/year can be used to estimate the generation of C\&DW in Brazilian municipalities (PINTO, 1999).

The existence of extensive areas for building landfills and the abundance of natural aggregates do not encourage the reduction of $C \& D W$ generation and its correct management. After the publication of CONAMA Resolution No. 448 of 2012, C\&DW landfills, known as inert waste landfill, started being called "class A waste landfills for reserving materials for future uses" (BRASIL, 2012). However, in practice, most landfills in Brazilian municipalities continue to store class A C\&DW (reusable or recyclable waste as aggregates) mixed with the other classes, due to the absence or inefficiency of sorting 
at the generating source. Despite extensive knowledge of C\&DW recycling techniques (ULSEN et al., 2013; CAZACLIU et al., 2014; VEGAS et al., 2015; PARANHOS et al., 2016; SILVA et al., 2017), the use of recycled aggregates (RA) to replace natural aggregates (NA) still faces resistance on the part of professionals from the construction industry. One of the main factors is the absence of standards regulating the quality of recycled aggregates. In addition, Brazilian standards limit the use of RA for paving and manufacturing concrete without structural function (ABNT, 2004a; 2004b).

The National Solid Waste Policy reinforces the obligation to correctly manage $C \& D W$, encouraging shared responsibility for the life cycle of products in order to minimize the volume of solid waste generated (BRASIL, 2010). However, most Brazilian municipalities often adopt corrective measures in the management of C\&DW, which represents a high burden for public cleaning systems (MARQUES NETO, 2009; CÓRDOBA, 2014). The main factors that corroborate this type of management are the scarcity of technical and financial resources, in addition to the lack of inspection by the responsible agencies (SCREMIN et al., 2014).

Economic fiscal instruments, such as specific C\&DW disposal fees, are considered adequate to encourage the correct management of this type of waste. However, the sudden application of such instruments, combined with the absence of awareness campaigns by the actors involved, can cause economic and environmental damages, such as the increase in irregular disposals.

Thus, it is necessary to evaluate the relationship between the specific disposal fees, so it is possible to gradually expand the charging system, depending on the associated environmental benefits. Therefore, as highlighted by Laurent et al. (2014) and Bovea and Powell (2016), life cycle assessment (LCA) is one of the indicated methodologies, as it allows determining the potential environmental impacts of waste management systems, supporting decision making and assisting in the comparison of two or more management scenarios.

Despite the existence of studies on the potential of fiscal economic instruments to improve C\&DW management (SÖDERHOLM, 2011; YUAN; WANG, 2014; AJAVI and OYEDELE, 2017), to date, there are no studies on the influence of these instruments on the environmental profile of management systems.

Therefore, the main goal of this study is evaluating the influence of the increase in the C\&DW disposal fee on the environmental profile of the management system of a medium-sized municipality located in the state of São Paulo, through life cycle assessment.

\section{Literature Review}

\section{Economic Instruments for Environmental Management}

According to Barbieri (2007), public environmental management is carried out by the government in line with an environmental policy, which in turn, comprises a set of objectives, guidelines and instruments. As a consequence of the diversity of environmental 
issues, public authorities use different instruments in order to avoid new problems, as well as to eliminate or minimize existing ones. The instruments can be classified into (i) command and control, (ii) economic and (iii) others, such as the support for scientific and technological development, environmental education, and provision of information to the population.

In Brazil, the most used instruments are those of command and control, also called direct regulations, applied through prohibitions, restrictions and obligations imposed on individuals and organizations, always based on legal norms (BARBIERI, 2007). Examples of this type of instrument are the pollutant emission standards, environmental licensing and zoning, and administrative and criminal sanctions (JURAS, 2009).

Economic instruments can be subdivided into fiscal and market instruments. Fiscal instruments promote the transfer of resources between private agents and the public sector, through taxes or subsidies, and market instruments involve transactions between private agents in markets regulated by the government, such as transferable emission allowances and deposit-return systems (BARBIERI, 2007).

Economic instruments are identified as the most appropriate to complement the strict and traditional command and control instruments (JURAS, 2009). However, they have some disadvantages, such as the difficulty of approval by the Legislative power, resistance of the affected agents, and the need for periodic evaluations and adaptations (IPEA, 2016).

The main objective of economic instruments is to create a mechanism for the "price" of environmental degradation to be paid by the person causing the damage. Thus, economic instruments encourage the change in the standards and behaviors of users/polluters, ensuring environmental quality and conservation (BURSZTYN and BURSZTYN, 2012).

The creation of new charges on emissions and polluting products, also called environmental taxes, contributes to the internalization of economic externalities, as they force producers and consumers to consider pollution costs or other environmental externalities in their economic decisions (BURSZTYN and BURSZTYN, 2012).

Environmental taxes can be calculated according to the weight of solid waste disposed of in landfills, increasing the average cost of final disposal. In this way, environmental taxes encourage waste reduction and the development of alternatives, such as recycling.

Fiscal economic instruments applied to the management of construction and demolition waste

Since the late 1980s, there has been a growing interest in the application of economic instruments in the formulation of environmental policies, such as taxes, fees, transferable emission allowances and deposit-return systems (SÖDERHOLM, 2011). The main reason for this is the fact that traditional regulations (command and control) often fail to provide flexible and cost-effective tools to reduce emissions (STAVINS, 2001).

As example of this is the fee on the solid waste destined for landfills and incinerators established in 1987 in Denmark. As described by Andersen (1998), this fee doubled 
the average cost of final disposal in landfills, and increased incineration costs by $70 \%$. Regarding C\&DW, if the waste delivered to the facilities was reused or recycled, the fee would be refunded at the time of delivery. At the same time, a fee on the use of raw materials in construction activities, such as sand and aggregates, was also created. This set of measures resulted in a reduction of 64\% in C\&DW disposal from 1987 to 1993, and in a significant increase in recycling rates, from 800,000 tons in 1991 , to more than 1.6 million tons in 1995. To this day, legislation and tax policies are the most used mechanisms to promote the minimization of C\&DW, and the establishment of disposal fees is one of the most notable practices reported in the literature (YUAN and WANG, 2014).

Ajavi and Oyedele (2017) point out that, to improve the effectiveness of these mechanisms, the opinion of the professionals involved (architects, engineers, designers, among others) should be considered. Box 1 presents the six main measures pointed out by UK professionals to improve the effectiveness of policies aimed at minimizing C\&DW disposal. The economic instruments are represented by measures 1 and 5, confirming their potential to improve the management of this type of waste.

Tax incentives and reductions appear as the main strategy, such as the reduction in the taxes paid by companies that recycle $C \& D W$, contributing to the competitiveness of the price of RA in relation to the corresponding NA, followed by the reduction in the taxes charged on equipment used in the management of C\&DW, such as small mobile crushers, which can produce RA to be used at the construction site itself, minimizing the number of disposals and the impacts of transportation (AJAVI and OYEDELE, 2017).

According to Söderholm (2011), countries that charge relatively high taxes on NA (such as the United Kingdom) achieve higher recycling rates. However, the author stresses the importance of understanding how a broader set of policies, in addition to taxes, interact with the aggregate market.

The fifth measure recommended may also be classified as an economic instrument, as it pertains to the increase in the C\&DW disposal fee, and the use of surplus rates as incentives. This measure is an important strategy, as it has the potential to raise the awareness of the construction sector in relation to the management of C\&DW to minimize costs, since high generation rates or inefficient sorting leads to high disposal fees (AJAVI and OYEDELE, 2017).

Box 1. Main measures to increase the effectiveness of policies for the minimization of construction waste indicated by professionals in the UK construction sector.

\begin{tabular}{|l|l|}
\hline Main measures & Main specific measures \\
\hline $\begin{array}{l}1-\text { Tax incentives and } \\
\text { reductions }\end{array}$ & • Reduction in taxes paid by producers of recycled aggregates; \\
\hline
\end{tabular}




\begin{tabular}{|c|c|}
\hline $\begin{array}{l}2-\text { Focus on the Project } \\
\text { stage }\end{array}$ & $\begin{array}{l}\text { - Deconstruction plan as part of the project; } \\
\text { - Increased attention to the project stage instead of the con- } \\
\text { struction in practice. }\end{array}$ \\
\hline $\begin{array}{l}3 \text { - Extension of the sus- } \\
\text { tainable design assessment } \\
\text { system }\end{array}$ & $\begin{array}{l}\text { - Allocation of points for the use of a pre-assembled/modular } \\
\text { system in large projects; } \\
\text { - Attribution of more points for the use of tools that minimize } \\
\text { waste, such as BREEAM (Environmental Assessment Method of } \\
\text { the Building Research Establishment). }\end{array}$ \\
\hline $\begin{array}{l}4 \text { - Increased severity of } \\
\text { existing legal instruments }\end{array}$ & $\begin{array}{l}\text { - Integration of the management of C\&DW in the evaluation } \\
\text { of construction companies; } \\
\text { - Requirement of the assignment of C\&DW management at } \\
\text { the construction site to an employee with no other functions; } \\
\text { - Requirement of the use of a fraction of recycled materials in } \\
\text { all projects. }\end{array}$ \\
\hline $\begin{array}{l}5-\text { Increased severity of } \\
\text { fiscal instruments }\end{array}$ & $\begin{array}{l}\text { - Increase in the disposal fee and use of surplus rates as incen- } \\
\text { tives; } \\
\text { - Increase in the disposal fee for mixed waste and reduction in } \\
\text { the disposal fee for sorted waste; } \\
\text { - Increase in the tax on natural aggregates and introduction of } \\
\text { a tax on the disposal of reusable materials in landfills. }\end{array}$ \\
\hline $\begin{array}{l}6 \text { - Promotion of waste } \\
\text { prevention }\end{array}$ & $\begin{array}{l}\text { - Improvement in the information on the quality, availability } \\
\text { and benefits of recycled materials; } \\
\text { - Development of a market structure and facilitation of access } \\
\text { to recycled materials. }\end{array}$ \\
\hline
\end{tabular}

Source: Adapted from AJAVI and OYEDELE (2017).

According to Coelho and Brito (2011), the establishment of C\&DW disposal fees also has the potential to encourage selective demolition. A study conducted by the authors concluded that the fees commonly charged on the disposal of C\&DW waste in Lisbon (Portugal) should increase from $90 \%$ to $150 \%$ for selective demolition to be able to economically compete with traditional demolitions.

In Hong Kong, one of the most significant C\&DW minimization practices was the adoption of a waste sorting system before the final disposal. From 2006 to 2012, 5.11 million tons of C\&DW were sorted due to the following changes in the fees: $\mathrm{HK} \$ 125 / \mathrm{t}$ of C\&DW disposed of in landfills; HK \$100/t of C\&DW delivered to sorting facilities; and $\mathrm{HK} \$ 27 / \mathrm{t}$ of C\&DW entirely composed of inert materials that can be accepted at public facilities for use as land filling and leveling materials (WEISHENG and HONGPING, 2012).

Studies on the inclusion of economic instruments in Brazilian environmental public policies (JURAS, 2009; IPEA, 2012; 2016) do not present specific examples or recommendations for the management of $C \& D W$, since the main focus is municipal solid waste.

However, it is important to highlight the existence of public initiatives aimed at 
improving the current taxation model in Brazil, in which, depending on the structure of the recycling chain, the taxes charged on recycled material may be higher than that of the equivalent raw material (LCA, 2014; CEMPRE, 2014).

As an example, Law No. 16,177/16 of the state of Ceará establishes a $61.11 \%$ reduction in the Tax on Circulation of Goods and Services (VAT) for products resulting from the recycling of plastics, paper, cardboard, construction waste and other recyclable materials, provided they have the Green Seal Certification issued by the State Superintendence for the Environment.

In the southeast region, there is a bill in the state of Rio de Janeiro (Bill No. $3,344 / 10$ ) that provides for VAT exemption for the sale or circulation of recycled products from C\&DW (SILVA, 2016).

The experiences reported in the international literature and national initiatives demonstrate the potential of economic instruments for improving the public management of $C \& D W$, mainly by reducing landfilling and encouraging recycling, which in turn, enables the replacement of natural aggregates by recycled ones. For these instruments to be effective, a previous study that considers the perspectives of stakeholders (generator, transporter, and the final destination operator) should be conducted, in addition to the joint adoption of command and control instruments, and the implementation of communication programs and environmental education involving the entire society.

\section{Methods}

The study of the environmental impact of solid waste management systems requires systematic data, survey methods and data comparisons so that the results can be interpreted accordingly and subsidize decision making. Therefore, life cycle assessment (LCA) is one of the most suitable methodologies for this purpose (CLIFT et al., 2000), and was thus used to study the influence of the increase in C\&DW deposition fees in the management system of the municipality of Limeira/SP.

\section{Description of the study area}

The municipality of Limeira, located $154 \mathrm{~km}$ from the city of São Paulo, belongs to the Administrative Region of Campinas and to the Hydrographic Basins of the Piracicaba, Capivari and Jundiaí Rivers. In 2018, the population was estimated at 292,497 inhabitants (SEADE, 2018), making it a medium-sized municipality. Limeira has a Municipal Landfill Complex, located $10 \mathrm{~km}$ from the city center, which includes a sanitary landfill for the disposal of municipal solid waste and non-hazardous industrial waste, and an inert landfill for the disposal of class A C\&DW and inert industrial waste. In this same place, there is an area reserved for the storage of class A C\&DW free of impurities and with suitable granulometry for paving the landfill's access routes and for use as cover material, as well as an area reserved for the sorting and final disposal of waste collected in the "Só Cacareco" Program, composed mainly of useless furniture (LIMEIRA, 2015). 
The C\&DW management system also includes 11 drop-off centers for small volumes, located in five strategic regions of the municipality that received large quantities of irregularly disposed C\&DW. The drop-off centers receive up to $1 \mathrm{~m}^{3}$ of $C \& D W$ per inhabitant every day, free of charge, in addition to recyclable materials (metal, paper, plastic, glass) and green waste (pruning and land cleaning waste) (LIMEIRA, 2015).

From 2005 to 2017, the average amount of C\&DW managed by the municipality was $1.45 \mathrm{~kg} /$ inhabitant/day, which corresponds to the waste collected by $14 \mathrm{C \& DW}$ transport companies and delivered to the Municipal Landfill Complex, to the C\&DW delivered by residents and autonomous transporters directly at the landfill and at drop-off centers, to the fraction generated in the construction works of the municipality itself, and to the fraction collected by the contractor responsible for urban cleaning and removal of rubbish from the areas of irregular disposal.

Large generators (construction and demolition companies) are responsible for the proper disposal of their waste, outsourcing this service to private companies, and so far, there is no record of the quantities generated by them (ROSADO and PENTEADO, 2018b). Thus, according to the municipal landfill's manager, it is estimated that $60 \%$ of the $C \& D W$ delivered come from large generators, and $40 \%$ from small generators.

According to the Official Journal of the Municipality, the C\&DW disposal fee is $\mathrm{R} \$ 15 / \mathrm{m}^{3}$, and volumes of up to $1 \mathrm{~m}^{3}$ are exempt from payment. Since 2015 , there has been a specific fee for buckets containing mixed C\&DW $\left(\mathrm{R} \$ 110 / \mathrm{m}^{3}\right)$, since this type of waste must be disposed of in the sanitary landfill, due to the risk of contamination. It is important to highlight that, according to the Brazilian standard (ABNT, 2004c), inert waste landfills do not require liners and leachate collection systems, which means that controlling the types of waste disposed in them is essential to avoid contamination of the soil and groundwater.

Table 1 shows the evolution of C\&DW disposal fees and the fines for irregular disposal of this type of waste, applied in accordance with Municipal Law No. 4812/2011, Complementary Law No. 650/2012, and other regulations of the municipality.

Table 1. Evolution of C\&DW disposal fees in the Municipal Landfill Complex, and fines for irregular disposal.

\begin{tabular}{llllllll} 
Fees & 2011 & 2012 & 2013 & 2014 & 2015 & 2016 & 2017 \\
Up to $1 \mathrm{~m}^{3} \mathrm{C} \& D W\left(\mathrm{R} \$ / \mathrm{m}^{3}\right)$ & 5.60 & 5.88 & \multicolumn{7}{c}{ Exempt from paying the disposal fee } \\
Over $1 \mathrm{~m}^{3} \mathrm{C} \& \mathrm{DW}\left(\mathrm{R} \$ / \mathrm{m}^{3}\right)$ & 8.00 & 8.39 & 9.69 & 10.32 & 12.00 & 14.00 & 15.00 \\
Contaminated $\mathrm{C} \& \mathrm{DW}\left(\mathrm{R} \$ / \mathrm{m}^{3}\right)$ & - & - & - & - & 89.87 & 97.81 & 110.00 \\
Fine for irregular disposal & & \multicolumn{7}{c}{$\begin{array}{c}\text { 200 UFESP } \\
\text { UFESP }(\mathrm{R} \$)\end{array}$} & 17.45 & 18.44 & 19.37 & 20.14 & 21.25 & 23.55 & 25.07 \\
\hline
\end{tabular}


The municipality published the C\&DW Municipal Management Plan in 2015, through Decree No. 304 of 2015 (LIMEIRA, 2015), in accordance with Conama Resolutions No. 307/2002 and No. 448/2012. However, no updates have been made so far, and some goals are yet to be met, such as: requiring that large generators disclose their C\&DW Management Plans, improving the management of drop-off centers, encouraging the recycling of $C \& D W$, intensifying inspection, and promoting environmental education activities (ROSADO and PENTEADO, 2018a), since irregular disposals are still frequent in some regions, representing approximately $7 \%$ of the total C\&DW managed by the municipality.

\section{Life Cycle Assessment}

LCA was carried out in accordance with ABNT standards 14,040 and 14,044 (ABNT, 2009a; 2009b).

The functional unit was defined as the amount of class A C\&DW produced by large generators (60\% of the total) in each year (2017 - current scenario; 2020, 2025 and 2030 - projections based on the current and proposed scenarios). Small generators (C\&DW generation of up to $1 \mathrm{~m}^{3} /$ day) were not considered, as they are exempt from paying disposal fees and, therefore, are not influenced.

The scenarios were developed considering the approaches adopted by Coelho and Brito (2011) and Weisheng and Hongping (2012), who pointed out the potential of increasing C\&DW disposal fees to minimize generation and/or increase reuse and recycling.

Thus, the analysis consisted of comparing the maintenance of the current C\&DW management system (current scenario) to a management system with increased C\&DW disposal fees, in order to increase or encourage reuse and recycling and minimize final disposal in landfills.

For this, two projections for the municipal C\&DW management system of Limeira were made:

- Current scenario: considering the update of $C \& D W$ disposal fees based on previous fees (approximately $\mathrm{R} \$ 2$ per year) and the lack of a recycling plant in the municipality, as well as the lack of incentives to minimize the disposal of C\&DW in landfills.

- Proposed scenario: considering the increase in C\&DW disposal fees aiming to minimize disposal in landfills, the existence of a recycling plant in the municipality, as well as recycling incentive programs.

Table 2 presents the main information used to project scenarios for the years 2020 , 2025 and 2030. C\&DW quantities were estimated based on population projections (SEADE, 2018) and the average C\&DW generation rate in Limeira per capita $(0.50 \mathrm{t}$ of C\&DW/inhabitant/year). 
Table 2 - Main information used to project scenarios for the years 2020, 2025 and 2030, based on the current C\&DW management system.

\begin{tabular}{|c|c|c|c|c|c|c|c|}
\hline \multirow{2}{*}{ Information } & \multicolumn{4}{|c|}{ Current scenario } & \multicolumn{3}{|c|}{ Proposed scenario } \\
\hline & 2017 & 2020 & 2025 & 2030 & 2020 & 2025 & 2030 \\
\hline $\begin{array}{l}\text { C\&DW disposal in the inert } \\
\text { landfill (\%) }\end{array}$ & 100 & 100 & 100 & 100 & 90 & 70 & 60 \\
\hline $\begin{array}{l}\text { C\&DW produced by large } \\
\text { generators and disposed of in } \\
\text { the inert landfill }(t)\end{array}$ & 77,708 & 82,668 & 84,586 & 85,739 & 74,401 & 59,210 & 51,443 \\
\hline $\begin{array}{l}\text { C\&DW disposal fee (above } \\
\left.1 \mathrm{~m}^{3}\right) \text { - large generators } \\
(\mathrm{R} \$ / \mathrm{t})\end{array}$ & 15.00 & 21.00 & 31.00 & 41.00 & 37.50 & 52.50 & 67.50 \\
\hline $\begin{array}{l}\text { Contaminated C\&DW dis- } \\
\text { posal fee }(\mathrm{R} \$ / \mathrm{t})\end{array}$ & 110.00 & 116.00 & 126.00 & 135.00 & 116.00 & 126.00 & 135.00 \\
\hline $\begin{array}{l}\text { C\&DW produced by small } \\
\text { generators and disposed of in } \\
\text { the inert landfill }(\mathrm{t})\end{array}$ & 51,805 & 55,112 & 56,391 & 57,159 & 55,112 & 56,391 & 57,159 \\
\hline $\begin{array}{l}\text { C\&DW disposal fee (up } \\
\left.\text { to } 1 \mathrm{~m}^{3}\right) \text { - small generators } \\
(\mathrm{R} \$ / \mathrm{t})\end{array}$ & \multicolumn{7}{|c|}{ Exempt from paying disposal fees } \\
\hline $\begin{array}{l}\text { C\&DW collected in public } \\
\text { areas - irregular disposal (t) }\end{array}$ & 9,748 & 10,371 & 10,611 & 10,756 & 10,371 & 10,611 & 10,756 \\
\hline $\begin{array}{l}\text { Fine for irregular disposal } \\
\text { (UFESP) }\end{array}$ & 200 & 300 & 400 & 500 & 300 & 400 & 500 \\
\hline $\begin{array}{l}\text { Percentage of C\&DW re- } \\
\text { cycled (\%) }\end{array}$ & 0 & 0 & 0 & 0 & 10 & 30 & 40 \\
\hline C\&DW recycled $(\mathrm{t})$ & 0 & 0 & 0 & 0 & 8,267 & 25,376 & 34,296 \\
\hline Recycling cost $(\mathrm{R} \$ / \mathrm{t})$ & - & - & - & - & 30.00 & 40.00 & 50.00 \\
\hline
\end{tabular}

Source: prepared by the authors based on data from the Limeira City Hall, 2018.

It is worth mentioning that the proposed scenario was projected considering that there would be no increase in irregular disposals, due to the existence of an efficient environmental monitoring and communication program regulating this type of irregular practice, in addition to the application of fines.

The fee for disposal of contaminated C\&DW is constant in both scenarios, as these values are considered adequate and an excessive increase could encourage irregular disposals. However, the proposed scenario requires the disclosure of C\&DW Management Plans and the creation of programs for provision of information about $C \& D W$ sorting in the construction site, as well as the mobilization of citizens regarding the prohibition of the contamination of buckets with waste that does not come from construction activities.

The C\&DW recycling percentages were adopted based on the current fraction of 
approximately 20\% (ABRECON, 2015), and projected assuming, as a positive factor, that the cost of delivering buckets to the Recycling Facility will always be lower than the cost of delivering them to the inert landfill, as well as that, as a negative factor, there will still be resistance from construction professionals to use recycled aggregates; therefore, most RA will be used for the works of the municipality, and with that, the maximum fraction of C\&DW recycled will be $40 \%$.

The system und (Figure 1) was prepared considering the environmental burden of the following stages:

- Operation of the inert landfill: consumption of diesel and lubricating oil to operate the equipment;

- Cleaning of irregular disposal areas: consumption of diesel and lubricating oil to operate the wheel loader used to collect C\&DW, and consumption of diesel to operate the truck used to transport C\&DW to the inert landfill (average distance of $12 \mathrm{~km}$ );

- C\&DW recycling: consumption of diesel and lubricating oil to operate the wheel loader used to feed the crusher, consumption of electricity to operate the equipment used in the recycling process, and consumption of water to control the emission of particulate matter in the recycling facility;

- Burdens avoided due to the C\&DW recycling process: consumption of explosives, diesel, lubricating oil and water to obtain natural aggregates, consumption of diesel and lubricating oil to operate the wheal loader used to feed the crusher, consumption of electrical energy to operate the equipment used to produce natural aggregates, and consumption of water to control the emission of particulate matter.

The life cycle inventories were prepared based on primary data obtained from the Municipality of Limeira, together with secondary data obtained from the Ecoinvent v3.1 database (2014) and the literature. The CML baseline methodology v.3.03 was used to determine the potential environmental impacts, with the support of the SimaPro 8.5.2.0 software. 
Figure 1. System boundary with the main inputs, outputs and avoided burdens in the current and proposed scenarios

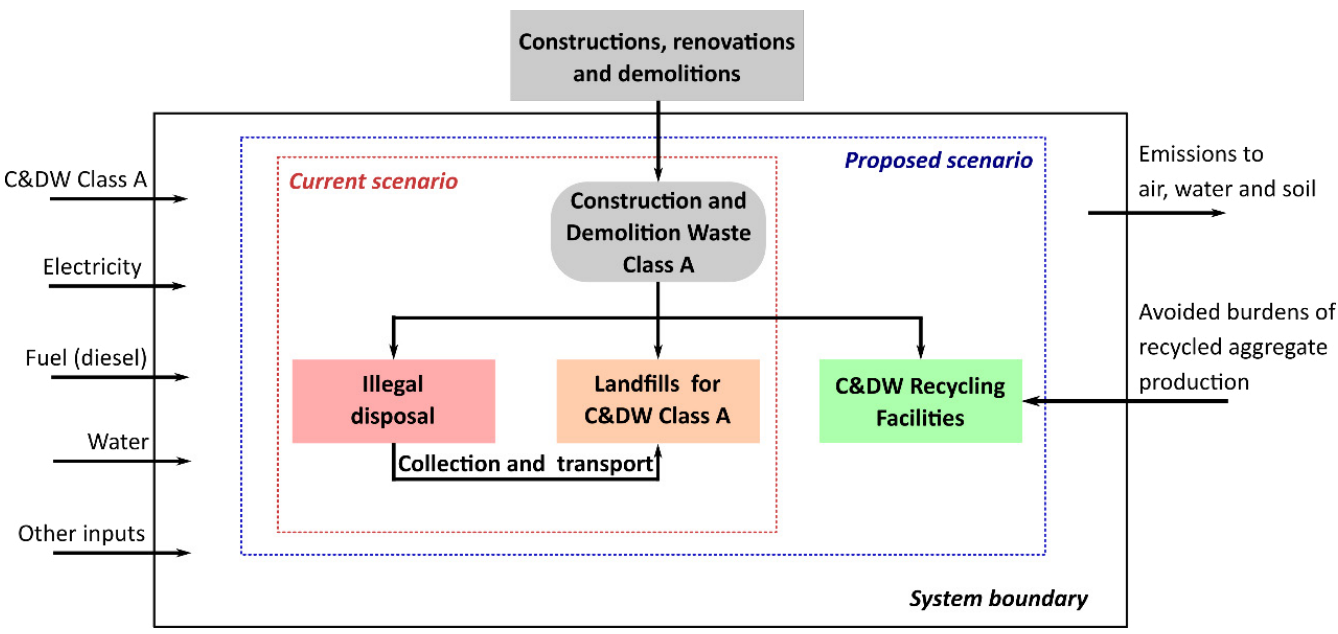

Source: Authors, 2018.

\section{Results and Discussion}

Based on the assumptions mentioned above, a Life Cycle Assessment was carried out to determine the environmental profile of the C\&DW management system of a medium-sized municipality based on the current scenario and its projections for 2020, 2025 and 2030, and in the scenarios proposed for 2020, 2025 and 2030, with the objective of verifying how the increase in disposal fees can influence environmental impacts.

Figure 2 shows the results of the potential environmental impacts for one person over a year, considering the global context. For all impact categories considered, the proposed scenarios have a lower number of environmental impacts than the scenarios projected according to the current panorama of the municipality's C\&DW management system. The scenario projected for 2030 has the lowest number of environmental impacts, indicating the effectiveness of using fiscal instruments in conjunction with command and control and information instruments to improve environmental performance. 
Figure 2. Normalized results for the current scenario based on 2017 data and projections for 2020, 2025 and 2030, considering the current and proposed scenarios

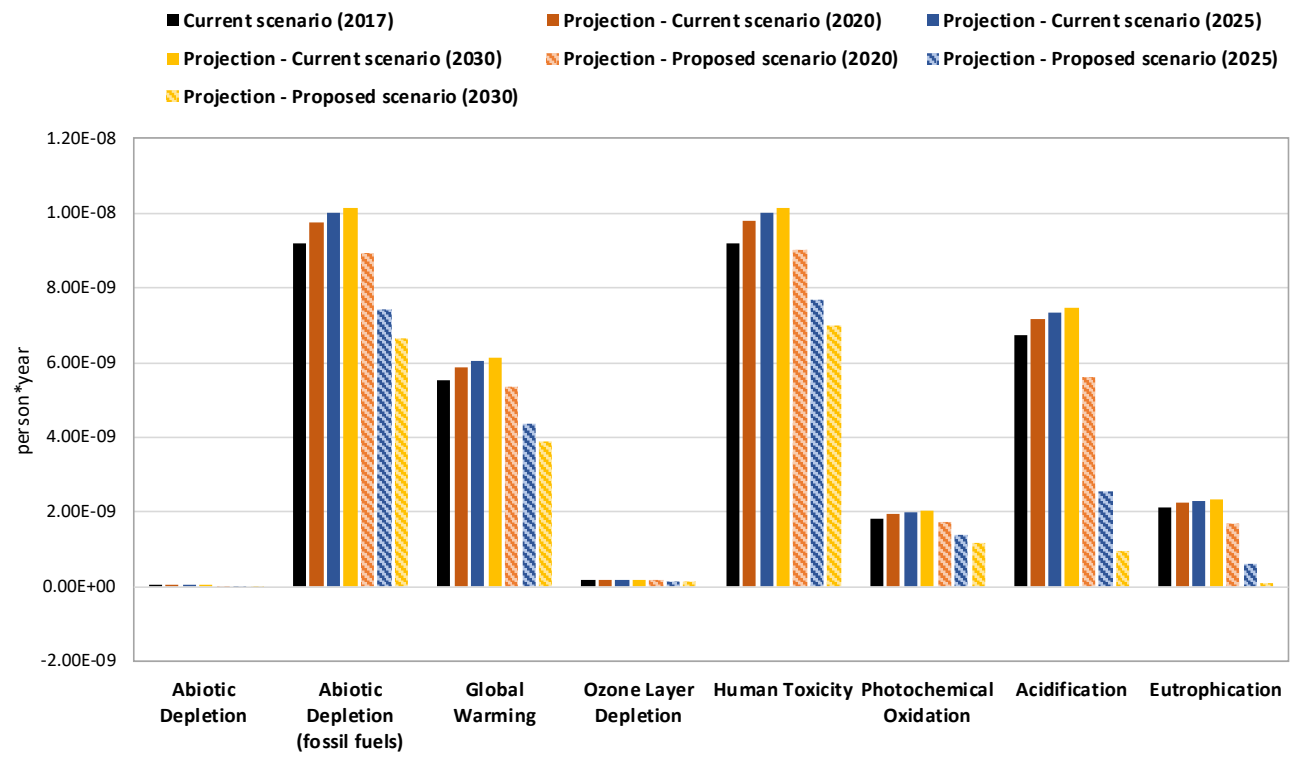

Source: Authors, 2018.

For the category "Abiotic depletion (fossil fuels)", the gradual reduction in impacts in the proposed scenarios ( $9 \%$ in 2020, 26\% in 2025 and 34\% in 2030) is mainly due to the decrease in the consumption of diesel used to operate the landfill. This factor also contributes to the reduction in $\mathrm{CO}_{2}$ (fossil) and nitrous oxide $\left(\mathrm{N}_{2} \mathrm{O}\right)$ emissions in the "Global Warming" category, reducing impacts in the scenario proposed for 2030 by $37 \%$ in relation to the scenario projected for the same year according to the current scenario.

The reduction in impacts in the category "Human Toxicity" (8\% in 2020, 23\% in 2025 and 31\% in 2030) is mainly due to the minimization of atmospheric emissions of nitrogen oxides and hydrogen fluoride derived from the extraction of the basalt used to produce natural aggregates.

However, compared to the other categories, "Human Toxicity" showed the smallest reductions in impacts due to pesticide emissions in the soil, resulting from the consumption of electricity in the $C \& D W$ recycling process. Pesticides come from the sugar cane crop, which participates in the Brazilian energy mix as biomass.

The recycling of C\&DW in the proposed scenarios contributes to a significant reduction in impacts in the "Acidification" category (22\% in 2020, 65\% in 2025 and $87 \%$ in 2030). The production of recycled aggregates avoids the production of natural aggregates, which in turn, avoids the extraction of natural raw materials, such as basalt, thereby reducing atmospheric emissions of ammonia and nitrogen oxides derived from the extraction process. 


\section{Conclusions}

The determination of the environmental profile of the current $C \& D W$ management system and future scenarios (2020, 2025 and 2030), considering the adoption of economic fiscal instruments, was carried out using the life cycle assessment methodology.

In summary, the results indicated that the scenario proposed for $2030(350 \%$ increase in the disposal rate compared to 2017) has the lowest number of environmental impacts for the impact categories evaluated. In addition, the results point to four categories as the most relevant: "Abiotic Depletion (fossil fuels)", "Global Warming", "Human Toxicity" and "Acidification".

For the categories "Abiotic Depletion (fossil fuels)" and "Global Warming", the gradual reduction in impacts results mainly from the decrease in the consumption of diesel used to operate the landfill. The reduction in impacts in the "Human Toxicity" and "Acidification" categories is related to the increase in C\&DW recycling rates, since the emissions of air pollutants derived from the extraction and production of natural aggregates are avoided.

Thus, the results indicate the effectiveness of using tax instruments to improve the environmental performance of municipal C\&DW management systems.

However, it should be mentioned that the increase in or adoption of specific fees (lower for class A C\&DW free from impurities and higher for class A C\&DW mixed with other types of waste) must be carried out in conjunction with communication and awareness programs aimed at citizens and private agencies responsible for the generation, collection, transportation and disposal of C\&DW. In addition, the simultaneous application of command and control instruments is recommended, in order to avoid the occurrence of irregular disposals.

\section{Acknowledgments}

The first author thanks CAPES - Coordination for the Improvement of Higher Education Personnel (Brazil) for the doctoral scholarship granted (Process No. 37-P-4907/2018). The authors also thank Espaço da Escrita - Pró-Reitoria de Pesquisa - UNICAMP - for the language services provided.

\section{References}

ABRECON. Relatório - Pesquisa Setorial 2014/2015. Associação Brasileira para Reciclagem de Resíduos da Construção Civil e Demolição, 2015. Available at: http://www.abrecon.org.br/ pesquisa_setorial/ (Accessed October 29, 2018).

ABRELPE. Panorama dos resíduos sólidos no Brasil 2018. Associação Brasileira de Limpeza Pública e Resíduos Especiais, 2019. 
AJAVI, S. O.; OYEDELE, L. O. Policy imperatives for diverting construction waste from landfill: Experts' recommendations for UK policy expansion. Journal of Cleaner Production, v. 147, p. 57-675, 2017.

ANDERSEN, M. S. Assessing the Effectiveness of Denmark's Waste Tax. Environment: Science and Policy for Sustainable Development, v. 40, n. 4, p. 10-15, 1998.

ASSOCIAÇÃO BRASILEIRA DE NORMAS TÉCNICAS. ABNT NBR 15.115 - Agregados reciclados de resíduos sólidos da construção civil - Execução de camadas de pavimentação - Procedimentos. Associação Brasileira de Normas Técnicas: Rio de Janeiro, 2004a.

. ABNT NBR 15.116 - Agregados reciclados de resíduos sólidos da construção civil Utilização em pavimentação e preparo de concreto sem função estrutural. Associação Brasileira de Normas Técnicas: Rio de Janeiro, 2004b.

. ABNT NBR 15.113 - Resíduos sólidos da construção civil e resíduos inertes - aterro diretrizes para projetos, implantação e operação. Associação Brasileira de Normas Técnicas: Rio de Janeiro, 2004c.

. ABNT NBR 14.040 - Gestão ambiental - Avaliação do Ciclo de Vida - Princípios e estrutura (Versão corrigida: 2014). Rio de Janeiro: ABNT, 2009a.

. ABNT NBR 14.044 - Gestão ambiental - Avaliação do Ciclo de Vida - Requisitos e orientações (Versão corrigida: 2014). Rio de Janeiro: ABNT, 2009b.

BARBIERI, J. C. Gestão ambiental empresarial - Conceitos, Modelos e Instrumentos. 2ª edição. São Paulo: Saraiva, 2007.

BOVEA, M.; POWELL, J. Developments in life cycle assessment applied to evaluate the environmental performance of construction and demolition wastes. Waste Management, v. 50, p. $151-172,2016$.

BRASIL. Ministério do Meio Ambiente. Resolução no 307 - Dispõe sobre a gestão dos resíduos da construção civil. Conselho Nacional do Meio Ambiente: Brasília, DF, 2002.

. Lei no 12.305, de 2 de agosto de 2010. Institui a Política Nacional de Resíduos Sólidos; altera a Lei no 9.605, de 12 de fevereiro de 1998; e dá outras providências. Brasília, DF, 2010.

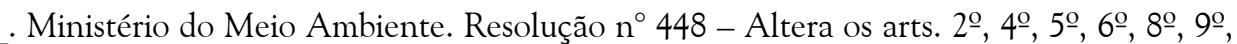
10, 11 da Resolução CONAMA n 307, de 5 de julho de 2002. Conselho Nacional do Meio Ambiente: Brasília, DF, 2012.

BURSZTYN, M. A.; BURSZTYN, M. Fundamentos de política e gestão ambiental - Caminhos para sustentabilidade. Rio de Janeiro: Garamond, 2012.

CAZACLIU, B. et al. The potential of using air jigging to sort recycled aggregates. Journal of Cleaner Production, v. 66, p. 46-53, 2014. 
CEMPRE (Compromisso Empresarial para Reciclagem). O impacto da desoneração tributária sobre a cadeia de reciclagem. CEMPRE informa número 135, maio/junho, 2014. Available at: http://cempre.org.br/cempre-informa/id/11/o-impacto-da-desoneracao-tributaria-sobre-a-cadeia-de-reciclagem (Accessed November 09, 2018).

CLIFT, R; DOIG, A; FINNVEDEN, G. The application of life cycle assessment to integrated solid waste management Part 1 - Methodology. Trans IChemE, v. 78, n. July, 2000.

COELHO, A.; BRITO, J. Economic analysis of conventional versus selective demolition - A case study. Resources, Conservation and Recycling, v. 55, p. 382-392, 2011.

CÓRDOBA, R. E. Estudo do potencial de contaminação de lixiviados gerados em aterros de resíduos da construção civil por meio de simulações em colunas de lixiviação. 2014. 340 p. Tese (Doutorado) - Curso de Engenharia Hidráulica e Saneamento, Universidade de São Paulo, São Carlos, 2014.

DAHLBO, H. et al. Construction and demolition waste management e a holistic evaluation of environmental performance. Journal of Cleaner Production, v. 107, p. 333-341, 2015.

ECOINVENT, 2014. The Life Cycle Inventory Data Version 3.1. Swiss Centre for Life Cycle Inventories.

IPEA (Instituto de Pesquisa Econômica Aplicada). Diagnóstico dos Instrumentos Econômicos e Sistemas de Informação para Gestão de Resíduos Sólidos. Coordenação: Cláudio Passos de Oliveira. Brasília: Ipea, 2012.

. Governança ambiental no Brasil: instituições, atores e políticas públicas. Organizadora: Adriana Maria Magalhães de Moura. Brasília: Ipea, 2016.

JURAS, A. G. M. J. Uso de Instrumentos Econômicos para a Gestão Ambiental: países da OCDE e América Latina. Estudo Consultoria Legislativa, 2009. Available at: http://www2.camara.leg.br/atividade-legislativa/estudos-e-notas-tecnicas/areas-da-conle/tema14/2009_4264. pdf (Accessed October 20, 2018).

LAURENT, A.; BAKAS, I.; CLAVREUL, J.; BERNSTAD, A.; NIERO, M.; GENTIL, E.; HAUSCHILD, M. Z.; CHRISTENSEN, T. H. Review of LCA studies of solid waste management systems - Part I: Lessons learned and perspectives. Waste Management, v. 34, p. 573-588, 2014.

LCA (Soluções estratégicas em economia). Ampliação e aperfeiçoamento dos mecanismos de desoneração tributária dos sistemas de logística reversa e estudo de impacto econômico da desoneração (estudo preparado para a CNI - Confederação Nacional da Indústria). 2014. Available at: http://www.mdic.gov.br/arquivos/dwnl_1395062357.pdf (Accessed November 09, 2018).

LIMEIRA (Município). Plano Municipal de Gestão de Resíduos da Construção Civil (PMGRCC) do Município de Limeira (SP). Prefeitura de Limeira, 2015. Available at: http://www. limeira.sp.gov.br/pml/sites/default/files/secretarias/desenvolvimento-turismo-inovacao/pmgrcc_ limeira_2015.pdf (Accessed October 25, 2018). 
MARQUES NETO, J. C. Estudo da Gestão Municipal dos resíduos de construção e demolição na bacia hidrográfica do Turvo Grande (UGRHI-15). Tese (Doutorado) - Programa de Pós-Graduação e Área de Concentração em Ciências de Engenharia Ambiental. Escola de Engenharia de São Carlos da Universidade de São Paulo, 2009.

PARANHOS, R. S. et al. A sorting method to value recycled concrete. Journal of Cleaner Production, v. 112, p. $2249-2258,2016$.

PINTO, T. P. Metodologia para a gestão diferenciada de resíduos sólidos da construção urbana. Tese (Doutorado) - Escola Politécnica, Universidade de São Paulo, São Paulo, 1999.

ROSADO, L. P.; PENTEADO, C. S. G. Análise da eficiência dos Ecopontos a partir do georreferenciamento de áreas de disposição irregular de resíduos de construção e demolição. Sociedade \& Natureza, v. 30, n. 2, p.164-185, 2018a.

ROSADO, L.P; PENTEADO, C.S.G. Uso de metodologia participativa na elaboração de Plano Municipal de Gestão de Resíduos da Construção Civil. Revista DAE, v. 66, n. 211, p. 20 -34, 2018b.

SCREMIN, L. B., CASTILHOS JUNIOR, A. B., ROCHA, J. C. Sistema de apoio ao gerenciamento de resíduos de construção e demolição para municípios de pequeno porte. Engenharia Sanitária Ambiental, v. 19, n. 2, p. 203-206, 2014.

SEADE (Sistema Estadual de Análise de Dados). Perfil do Municípios Paulistas - 2018. Available at: http://www.perfil.seade.gov.br (Accessed October 22, 2018).

SILVA, E. L. Desenvolvimento de fluxograma de beneficiamento para produção de agregados minerais reciclados e aplicações tecnológicas dos mesmos. Dissertação (Mestrado) - Programa de Pós-Graduação em Ciência dos Materiais e Metalurgia. Pontifícia Universidade Católica do Rio de Janeiro, 2016.

SILVA, R. V.; BRITO, J. de; DHIR, R. K. Availability and processing of recycled aggregates within the construction and demolition supply chain: A review. Journal of Cleaner Production, v. 143, p. 598-614, 2017.

SINDUSCON-SP. Gestão ambiental dos resíduos da construção civil - avanços institucionais e melhorias técnicas. Sinduscon-SP, 2015.

SÖDERHOLM, P. Taxing virgin natural resources: Lessons from aggregates taxation in Europe. Resources, Conservation and Recycling, v. 55, p. 911-922, 2011.

STAVINS, R. N. Experience with Market-Based Environmental Policy Instruments. Washington, DC: Discussion Paper 01 - 58, Resources for the Future, 2001. Available at: http://www.rff. org/files/sharepoint/WorkImages/Download/RFF-DP-01-58.pdf (Accessed October 30, 2018).

ULSEN, C.; KAHN, H.; HAWLITSCHEK, G.; MASINI, E. A.; ANGULO, S. C. Separability studies of construction and demolition waste recycled sand. Waste Management, v. 33, p. 656-662, 2013. 
UMAR, U. A.; SHAFIQ, N.; MALAKAHMAD, A.; NURUDDIN, M. F.; KHAMIDI, M. F. A review on adoption of novel techniques in construction waste management and policy. Journal of Material Cycles and Waste Management, v.19, p. 1361-1373, 2017.

VEGAS, I.; BROOS, K.; NIELSEN, P.; LAMBERTZ, O.; LISBONA, A. Upgrading the quality of mixed recycled aggregates from construction and demolition waste by using near-infrared sorting technology. Construction and Building Materials, v. 75, p. 121-128, 2015.

WEISHENG, L.; HONGPING, Y. Off-site sorting of construction waste: What can we learn from Hong Kong? Resources, Conservation and Recycling, v. 69, p. 100-108, 2012.

YAZDANBAKHSH, A. A bi-level environmental impact assessment framework for comparing construction and demolition waste management strategies. Waste Management, v.77, p. 401412, 2018.

YUAN, H.; WANG, J. A system dynamics model for determining the waste disposal charging fee in construction. European Journal of Operational Research, v. 237, p. 988-996, 2014. 
Laís Peixoto Rosado

ఐ laispr@gmail.com

ORCiD: https://orcid.org/0000-0002-5978-8408
Submitted on: $31 / 12 / 2018$

Accepted on: 25/08/2020

2020;23:e00321

\section{Carmenlucia Santos Giordano Penteado}

曰clucia@unicamp.br

ORCiD: https://orcid.org/0000-0001-5731-7947

How to cite: ROSADO, L. P.; PENTEADO, C. S. G. Municipal management of construction and demolition waste: influence of disposal fees. Ambiente $\mathbb{\&}$ Sociedade. São Paulo, v. 23, p. 1-19, 2020. 


\title{
Gestão municipal dos resíduos da construção civil: influência da taxa de disposição em aterros
}

\author{
Laís Peixoto Rosado \\ Carmenlucia Santos Giordano Penteado
}

São Paulo. Vol. 23, 2020

Resumo: Os instrumentos econômicos fiscais são um dos principais Artigo Original mecanismos para promover a melhoria do gerenciamento dos resíduos da construção civil (RCC), sendo a diferenciação das taxas para a disposição final em aterros uma das práticas mais efetivas. Este trabalho analisou a influência do aumento da taxa para disposição dos RCC em aterro, considerando um sistema municipal de gerenciamento. $\mathrm{O}$ perfil ambiental do cenário atual e dos cenários propostos, projetados de acordo com a adoção de instrumentos econômicos fiscais, foram determinados por meio da avaliação do ciclo de vida. Os resultados indicaram que o cenário proposto para 2030 (aumento de 350\% na taxa de disposição do aterro em relação a 2017) apresenta os menores impactos ambientais, indicando os benefícios potenciais do uso de instrumentos fiscais.

Palavras-chave: Resíduos da construção civil; gestão; gerenciamento; instrumentos econômicos; avaliação do ciclo de vida.

Como citar: ROSADO, L. P; PENTEADO, C. S. G. Gestão municipal dos resíduos da construção civil: influência da taxa de disposição em aterros. Ambiente \& Sociedade. São Paulo, v. 23, p. 1-19, 2020. 


\title{
Gestión municipal de residuos de la construcción civil: influencia de la tasa de cobro para la disposición final en vertederos
}

\author{
Laís Peixoto Rosado \\ Carmenlucia Santos Giordano Penteado
}

São Paulo. Vol. 23, 2020

Resumen: Los instrumentos económicos fiscales son uno de los princi-

Artículo original

pales mecanismos para promover la mejora de la gestión de los residuos de la construcción civil (RCC), siendo la tasa de cobro para la disposición final en vertederos una de las prácticas más efectivas. Este trabajo analizó la influencia del aumento de la tasa para la disposición de los RCC en vertederos, considerando un sistema municipal de gestión. El perfil ambiental del escenario actual y de los escenarios propuestos, proyectados de acuerdo con la adopción de instrumentos económicos fiscales, fueron determinados por medio del análisis del ciclo de vida. Los resultados indicaron que el escenario propuesto para 2030 (aumento del $350 \%$ en la tasa de disposición del vertedero en relación a 2017) presenta los menores impactos ambientales, indicando los beneficios potenciales del uso de instrumentos fiscales.

Palabras-clave: Residuos de la construcción civil; gestión; instrumentos económicos; análisis del ciclo de vida.

Como citar: ROSADO, L. P.; PENTEADO, C. S. G. Gestión municipal de residuos de la construcción civil: influencia de la tasa de cobro para la disposición final en vertederos. Ambiente $\boldsymbol{\&}$ Sociedade. São Paulo, v. 23, p. 1-19, 2020. 